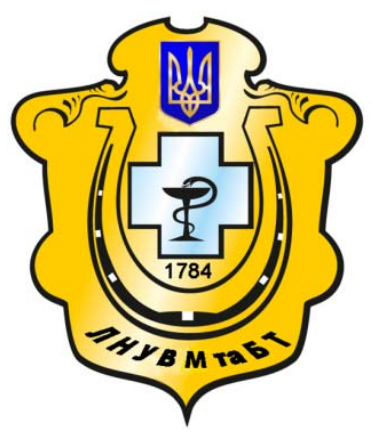

Науковий вісник Львівського національного університету ветеринарної медицини та біотехнологій імені С.3. Гжицького

Scientific Messenger of Lviv National University of Veterinary Medicine and Biotechnologies named after S.Z. Gzhytskyj

doi:10.15421/nvlvet6620

ISSN 2413-5550 print

ISSN $2518-1327$ online

$\underline{\text { http://nvlvet.com.ua/ }}$

УДК 619:616.092:636.597

\title{
Функціональний стан органів імуногенезу каченят у критичні періоди постнатального онтогенезу
}

\author{
A.О. Крог \\ Krogh@ukr.net \\ Львівський національний університет ветеринарної медицини та біотехнологій імені С.З. Гжиџького, \\ вул. Пекарська, 50, м. Львів, 79010, Україна
}

\begin{abstract}
Дослідження функиіонального стану органів імуногенезу молодняку качок в критичні періоди росту і розвитку має важливе значення при розведенні і утриманні цього виду птииі з огляду на удосконалення системи оиінки імунного статусу їх організму. Такі підходи дають можливість своєчасно попередити розвиток імунодефіцитних станів організму качок, розробити удосконалені схеми годівлі з метою підвищення потенціалу продуктивності. У статті представлені результати дослідження функиіонального стану тимусу, бурси Фабриціуса, селезінки клінічно здорового молодняку качок пекінської породи у критичні періоди постнатального онтогенезу, вирощених в умовах господарства с. Миклашів Пустомитівського району, Львівської області. Встановлено, що в каченят з 2-до 45-добового віку збільшується абсолютна маса досліджуваних органів імуногенезу на тлі зменшення відносної маси та індексу. Однак, про функціонування органів імуногенезу каченят у критичні періоди росту і розвитку свідчать власне числові значення відносної маси та індексу. Яскраво виражені зміни індексу органів імуногенезу спостерігали на межі між 14 та 21 добою життя каченят, що можна виділяти як один з критичних імунологічних періодів постнатального онтогенезу цього виду птиці. Отримані числові значення індексу тимусу, бурси Фабриціуса, селезінки каченят, які перебувають в межах фізіологічної норми, свідчать про активний перебіг специфічних імуноморфологічних реакиій в изих імунокомпетентних органах. При достатньо високому індексу бурси та зниженому індексу селезінки можна допускати розвиток адаптаційно-компенсаторної реакиії В-ланки імунітету та відсутність розвитку імунодефіцтного стану в організмі каченят 45-добового віку.
\end{abstract}

Ключові слова: тимус, бурса Фабриціуса, селезінка, каченята, критичні періоди, онтогенез, імунна система.

\section{Функциональное состояние органов иммуногенеза утят в критический периоды постнатального онтогенеза}

\author{
А.А. Крог \\ Krogh@ukr.net
}

Львовский национальный университет ветеринарной медицины и биотехнологий имени С.3. Гжицкого, ул. Пекарская, 50, г. Львов, 79010, Украина

\begin{abstract}
Исследование функционального состояния органов иммуногенеза молодняка уток в критические периоды роста и развития имеет важное значение при разведении и содержании этого вида птицы с учетом совершенствования системы оценки иммунного статуса их организма. Такие подходы дают возможность своевременно предупредить развитие иммунодефицитных состояний организма уток, разработать усовершенствованные схемы кормления с иелью повымения потенциала продуктивности. В статье представлены результаты исследования функционального состояния тимуса, бурсы Фабрициуса, селезенки клинически здорового молодняка уток пекинской породы в критические периоды постнатального онтогенеза, выращенных в условиях хозяйства с. Миклашев Пустомытовского района Львовской области. Установлено, что в утят с 2 до 45-суточного возраста увеличивается абсолютная масса исследуемых органов иммуногенеза на фоне уменьшения относительной массы и индекса. Однако, о функционировании органов иммуногенеза утят в критические
\end{abstract}

\section{Citation:}

Krogh, A.O. (2016). Functional state of ducklings immune organs in critical periods of postnatal ontogenesis. Scientific Messenger LNUVMBT named after S.Z. Gzhytskyj, 18, 2(66), 92-95. 
периоды роста и развития свидетельствуют собственно числовые значения относительной массы и индекса. Ярко выраженные изменения индекса органов иммуногенеза наблюдали на границе между 14 и 21 сутками жизни утят, что можно выделять как один из критических иммунологических периодов постнатального онтогенеза данного вида птицы. Полученные числовые значения индекса тимуса, бурсы Фабрициуса, селезенки утят, которые находятся в пределах физиологической нормы, свидетельствуют об активном течение специфических иммуноморфологические реакиий в этих иммунокомпетентных органах. При достаточно высоком индекса бурсы и пониженном индекса селезенки можно допускать развитие адаптационно-компенсаторной реакции В-звена иммунитета и отсутствие развития имунодефицтного состояния в организме утят 45-суточного возраста.

Ключевые слова: тимус, бурса Фабрициуса, селезенка, утята, критические периоды, онтогенез, иммунная система.

\title{
Functional state of ducklings immune organs in critical periods of postnatal ontogenesis
}

\author{
A.O. Krogh \\ Krogh@ukr.net \\ Lviv National University of Veterinary Medicine and Biotechnologies named after S.Z. Gzhytskyi, \\ Pekarska Str., 50, Lviv, 79010, Ukraine
}

The study of the functional state of immunogenesis young ducks during critical periods of growth and development is important for breeding and keeping birds of this species in view of improving the system of evaluation of the immune status of the organism. Such approaches make it possible to warn the development of immunodeficiencies body ducks develop improved feeding schemes to improve capacity performance. In the article are given results of the study of the functional state of the clinically healthy young duck's thymus, bursa Fabricius, spleen in critical periods of postnatal ontogenesis, whose were grown in conditions of Myklashiv farms of Pustomyty district, Lviv region. It is established the increasing of duck's absolute mass of immunogenesis organs on a background of reducing the relative weight and index. However, the functioning of immunogenesis ducklings in critical periods of growth and development of the actual numerical values indicating the relative weight and index. Pronounced changes in the index of immunogenesis observed on the border between 14 and 21 ducklings era of life that can be isolated as one of the critical periods of postnatal ontogenesis immunological this type of bird. The result is the index of thymus, bursa Fabricius, spleen ducklings who are within the physiological norm, show active progress imunomorfolohichnyh specific immune responses in these organs. At sufficiently high index seminary and reduced spleen index can prevent the development of adaptive-compensatory reactions $B$ immunity and lack of imunodefitstnoho state body ducklings 45-day age.

Key words: thymus, bursa Fabricius, spleen, ducks, critical periods, ontogenesis, immune system.

\section{Вступ}

Критичні періоди онтогенезу, як вказують дослідники, виявляються на межі етапів, періодів і рідше стадій розвитку птиці, при цьому кожна критична фаза визначає становлення функцій організму і його систем на наступний етап розвитку, а організм у цей період є найбільш чутливим до впливу зовнішніх факторів (Teltsov et al., 1993). Дослідження функціонального стану органів імуногенезу молодняку качок в критичні періоди росту і розвитку має важливе значення при розведенні і утриманні цього виду птиці з огляду на удосконалення системи оцінки імунного статусу їх організму. Такі підходи дають можливість своєчасно попередити розвиток імунодефіцитних станів організму качок, розробити удосконалені схеми годівлі з метою підвищення потенціалу продуктивності (Byrman and Hromov, 2001). Досліджуючи особливості функціональної адаптації організму качок в постнатальному онтогенезі, науковці виділяють критичні періоди їх росту і розвитку, що співпадають $31-$ 25 добою життя (інтенсивний розвиток травної системи і м'язової тканини), 60-150 добою життя (ювенальна линька), 150-300 добою життя (початок яйцекладки, формування репродуктивної системи і залоз внутрішньої секреції), 300-360 добою життя (закінчення яйцекладки та линька, яка супроводжується повним оновленням дрібного і середнього пір'я) (Teltsov and Shashanov, 1998). Вивчаючи закономір- ності розвитку, будови і функціонування органів імуногенезу качок, було встановлено, що ріст тимусу в них відбувається до 120-добового віку і закінчується 3 настанням статевої зрілості (яйцекладки) (Klymenko, 2000; Melnyk, 2012; Stehnei, 2013). Що стосується бурси Фабриціуса качок, наявні повідомлення у літературі свідчать про зниження іiі індексу до двохмісячного віку, а за іншими даними - до 120добового віку бурса характеризується повністю завершеною інволюцією (Yakymenko and Yakymenko, 2011; Topuryia and Bokov, 2013). Отримані результати $\epsilon$ суперечливими та потребують більш детального вивчення, тому метою нашої роботи було з'ясувати фізіологічні аспекти функціонування центральних i периферичних органів імунної системи каченят у критичні періоди раннього онтогенезу.

\section{Матеріал і методи досліджень}

Дослід було проведено в умовах господарства с. Миклашів Пустомитівського району, Львівської області на клінічно здоровому молодняку качок пекінської породи. Утримання птиці відповідало загальноприйнятим технологічним вимогам комбінованого вирощування на відгодівельних майданчиках і в таборах (вигульне утримання з вільним доступом до напувалок та годівниць). Температурний та світловий режими відповідали рекомендованим нормам. Вся птиця одержувала стандартний комбікорм (СК), збалансований за 
поживними і біологічно активними речовинами, який рекомендований для даного віку згідно технології утримання. Для досягнення поставленої мети у 2-, 14-, 21- і 45-добовому віці було відібрано по 5 каченят у кожному віковому періоді. Після легкого ефірного наркозу методом гострого знекровлення був проведений забій птиці та відібрано для досліджень тимус, бурсу Фабриціуса та селезінку. Усі втручання та забій молодняку птиці проводилися 3 дотриманням вимог «Європейської конвенції про захист хребетних тварин, які використовуються для експериментальних і наукових цілей» (Страсбург, 1986), ухвали Першого національного конгресу з біоетики (Київ, 2001) - «Загальні етичні принципи експериментів на тваринах» та 3 дотриманням принципів гуманності, викладеними у директиві Європейської Спільноти. При виконанні роботи використовували загальноприйняті макроскопічні методи досліджень: після анатомічного препарування органів визначали топографію, форму, колір, консистенцію, абсолютну масу органів за допомогою вагів лабораторних технічних 4 класу точності (ВЛКТ-500 М) та відносну масу органів (Horalskyi, 2005). Індекс тимуса, бурси Фабриціуса, селезінки визначали як відношення маси цих органів (г) до маси тіла птиці (г), помноженого на 1000 (Hutsol and Kondratev, 1988). Різниці статистично вірогідними вважали при $\mathrm{p}<0,05$ $-{ }^{*}, \mathrm{p}<0,01-{ }^{* *}, \mathrm{p}<0,001-{ }^{* * *}$ у порівнянні до вихідного вікового періоду.

\section{Результати та їх обговорення}

Отримані результати досліджень підтверджують дані літератури про топографію тимуса в каченят, який розташований в задній третині шиї вздовж трахеї під поверхневою фасцією (Klymenko, 2000). Він не мав грудної частини і був представлений тільки парними шийними частинами, які складалися з окремих часток, ізольованих та з'єднаних між собою пухкою сполучною тканиною. На відміну від тимуса курей, тимус каченят не заходив в грудо-черевну порожнину. У каченят 2-, 14-, 21- і 45-добового віку права частина тимуса налі- чувала 5-8 овальних часток, ліва частина 4-6 овальних часток сірувато-рожевого кольору, що співпадає 3 даними, отриманими дослідниками раніше (Klymenko, 2000; Melnyk, 2012). Бурса Фабриціуса, що являє собою дивертикул дорсальної стінки проктодеума клоаки, з'єднаний короткою вузькою протокою, у каченят 2-, 14-, 21 і 45-добового віку була витягнутої конусоподібної форми. Селезінка каченят досліджуваних вікових груп мала трикутну форму; у частини особин (30 \%) поряд 3 основною селезінкою виявлялися додаткова селезінка масою від 4 до 50 мг, розташована в безпосередній близькості до основної, або віддалена і лежала вздовж черевної аорти.

Встановлено, що в каченят 2-добового віку абсолютна маса тимусу складала 0,172 $\pm 0,093$ г, що було найнижче у порівнянні з наступними віковими періодами (таблиця 1). У той час, відносна маса та індекс тимусу становили $0,2586 \pm 0,025 \%$ та 2,586 $\pm 0,253$ (таблиця 2, 3). Отримані числові значення були найвищими по відношення до інших вікових груп каченят. Абсолютна маса бурси та селезінки, що складало відповідно 0,163 $\pm 0,078$ та 0,053 $\pm 0,071$ г, виявилася найнижчою, порівняно $з$ каченятами старших вікових груп. У той час, відносна маса та індекс бурси складали $0,2421 \pm 0,065 \%$ та 2,421 $\pm 0,160$ (таблиця 2, 3). Отримані числові значення були найвищими по відношення до інших вікових груп каченят. Що стосується селезінки, то іï відносна маса та індекс були вищими, порівняно з каченятами інших вікових груп.

Виявлено, що у каченят 14-добового віку абсолютна маса тимусу, бурси, селезінки збільшувалася, порівняно з каченятами 2-добового віку, проте вірогідних міжгрупових різниць виявлено не було. Збільшувалася і відносна маса та індекс селезінки, тоді коли відносна маса тимуса і бурси зменшувалася до $0,1607 \pm 0,052 \%$ і $0,2008 \pm 0,078 \%$, порівняно з каченятами 2-добового віку. Що стосується індексу тимусу, виявлено зменшення числового значення цього показника на 37,9\% (p < 0,05) у каченят 14-добового віку по відношенню до аналогів 2-добового віку.

Таблиия 1

Абсолютна маса органів імуногенезу каченят у критичні періоди онтогенезу,,$(\mathbf{M} \pm \mathbf{m}, \mathbf{n}=\mathbf{5})$

\begin{tabular}{|l|c|c|c|}
\hline Вік, діб & Тимус & Бурса Фабриціуса & Селезінка \\
\hline 2 & $0,172 \pm 0,093$ & $0,163 \pm 0,078$ & $0,053 \pm 0,071$ \\
\hline 14 & $0,246 \pm 0,105$ & $0,312 \pm 0,140$ & $0,143 \pm 0,094$ \\
\hline 21 & $0,736 \pm 0,124^{* *}$ & $0,704 \pm 0,171^{*}$ & $0,286 \pm 0,101^{* *}$ \\
\hline 45 & $1,493 \pm 0,159^{* * *}$ & $2,095 \pm 0,364^{* *}$ & $0,445 \pm 0,116^{* * *}$ \\
\hline
\end{tabular}

Відносна маса органів імуногенезу каченят у критичні періоди онтогенезу, \%, (M \pm m, $\mathbf{n}=5)$

Таблиия 2

\begin{tabular}{|l|c|c|c|}
\hline \multicolumn{1}{|c|}{ Вік, діб } & Тимус & Бурса Фабриціуса & Селезінка \\
\hline 2 & $0,259 \pm 0,025$ & $0,242 \pm 0,065$ & $0,081 \pm 0,007$ \\
\hline 14 & $0,161 \pm 0,052$ & $0,209 \pm 0,078$ & $0,094 \pm 0,040$ \\
\hline 21 & $0,152 \pm 0,031^{*}$ & $0,142 \pm 0,039^{*}$ & $0,059 \pm 0,026$ \\
\hline 45 & $0,143 \pm 0,039^{*}$ & $0,192 \pm 0,017$ & $0,040 \pm 0,010^{*}$ \\
\hline
\end{tabular}

Установлено, що в каченят 21-добового віку абсолютна маса тимусу, бурси, селезінки вірогідно збільшувалася в 4,3-5,4 разів ( $<0,05-0,01)$, порівняно 3 каченятами 2-добового віку (таблиця 1). Проте, відносна маса досліджуваних нами органів імуногенезу зменшувалися відповідно на 41,2\% (p < 0,05), 41,4 \%
( $<<0,05)$ i 27,1\%. В каченят 21-добового віку спостерігали вірогідне зменшення індексу тимусу, бурси на $41,2 \%(\mathrm{p}<0,01)$ та $41,4 \%(\mathrm{p}<0,01)$, а також тенденцію до зменшення індексу селезінки до 0,589 $\pm 0,076$, порівняно з каченятами 2-добового віку (таблиця 3). 
Встановлено найвищі числові значення абсолютної маси тимусу, бурси, селезінки в каченят 45добового віку, що було відповідно в 8,7 разів, 12,9 разів та 8,4 разів $(\mathrm{p}<0,01-0,001)$ більше, порівняно 3 каченятами 2-добового віку (таблиця 1).

Разом 3 тим, числові значення відносної маси та індексу досліджуваних нами органів імуногенезу каченят 45-добового віку виявилися найнижчими у порівнянні з попередніми віковими групами молодняку птиці. Зокрема, індекс тимусу, бурси, селезінки був відповідно на 44,7\% (p<0,01), 62,0\% (p<0,05) та
$50,2 \%(\mathrm{p}<0,01)$ нижчим, порівняно 3 каченятами 2добового віку (таблиця 3).

Отримані результати вказують на те, що числові значення абсолютної маси органів імуногенезу не являються інформативним показником, який би відображав функціональний стан імунної системи каченят у віковому аспекті з 2 до 45 доби життя. Про функціонування органів імуногенезу каченят у критичні періоди росту і розвитку свідчать власне числові значення відносної маси та індексу.

Індекс органів імуногенезу каченят у критичні періоди онтогенезу, $(\mathrm{M} \pm \mathbf{m}, \mathbf{n}=5)$

\begin{tabular}{|c|c|c|c|}
\hline Вік, діб & Тимус & Бурса Фабриціуса & Селезінка \\
\hline 2 & $2,586 \pm 0,253$ & $2,421 \pm 0,160$ & $0,808 \pm 0,074$ \\
\hline 14 & $1,607 \pm 0,180^{*}$ & $2,008 \pm 0,194$ & $0,938 \pm 0,101$ \\
\hline 21 & $1,521 \pm 0,190^{* *}$ & $1,419 \pm 0,173^{* *}$ & $0,589 \pm 0,076$ \\
\hline 45 & $1,429 \pm 0,278^{* *}$ & $1,919 \pm 0,130^{*}$ & $0,402 \pm 0,056^{* *}$ \\
\hline
\end{tabular}

Незважаючи на зростання абсолютної маси органів імуногенезу установлена тенденція і вірогідне зменшення відносної маси та індексу тимусу, бурси, селезінки в каченят до 45-добового віку. Яскраво виражені зміни індексу органів імуногенезу спостерігали на межі між 14 та 21 добою життя каченят, що можна виділяти як один $з$ критичних імунологічних періодів постнатального онтогенезу цього виду птиці. Разом 3 тим, отримані числові значення індексу тимусу і бурси каченят 45-добового віку, що складають відповідно $1,429 \pm 0,278$ та $1,919 \pm 0,130$, можуть свідчити про перебіг специфічних імуноморфологічних реакцій в цих імунокомпетентних органах в межах фізіологічної норми, що підтверджують дані Апатенка B.M. (Apatenko, 1994). За результатами автора, в птиці на наявність акцидентальної трансформації тимусу вказує індекс в межах 1,5 - 3,5, бурси Фабриціуса 1,5 - 2,5; на розвиток імунодефіцитного стану вказує зміна індексу тимусу і бурси Фабриціуса нижче 1,5 i 1,0 (Apatenko, 1994). При достатньо високому індексу бурси та зниженому індексу селезінки $(0,402 \pm 0,056)$ можна допускати розвиток адаптаційно-компенсаторної реакції В-ланки імунітету та відсутність розвитку імунодефіцтного стану в організмі каченят 45-добового віку.

\section{Висновки}

У критичні періоди постнатального онтогенезу спостерігається тенденція до зменшення індексу тимусу, бурси, селезінки відповідно на 44,7\% (р < 0,01), $62,0 \%(\mathrm{p}<0,05)$ та 50,2\% $(\mathrm{p}<0,01)$ в каченят $45-$ добового віку, порівняно 3 каченятами 2-добового віку. Отримані числові значення свідчать про перебіг специфічних імуноморфологічних реакцій в цих імунокомпетентних органах в межах фізіологічної норми та про відсутність розвитку імунодефіцтного стану в організмі каченят 45-добового віку.

Перспективи подальших досліджень. У подальшому планується дослідження морфологічного стану органів імуногенезу каченят у різні вікові періоди онтогенезу.

\section{Бібліографічні посилання}

Apatenko, V.M. (1994). Veterynarna imunolohiia ta imunopatolohiia. K.: Urozhai (in Ukrainian).

Byrman, B.Ia., Hromov, Y.N. (2001). Ymmunodefytsytы u ptyts. Mynsk: Byznesofest (in Russian).

Hutsol, A.A., Kondratev, B.Iu. (1988). Praktycheskaia morfometryia orhanov y tkanei: Dlia vracheipatolohoanatomov. Tomsk: Yzd. Tom. un-ta (in Russian).

Horalskyi, L.P., Khomych, V.T., Kononskyi, O.I. (2005). Osnovy histolohichnoi tekhniky i morfofunktsionalni metody doslidzhen u normi ta pry patolohii: navch. posib. Zhytomyr: Polissia (in Ukrainian).

Klymenko, O.M. (2000). Strukturni osoblyvosti tymusa s.-h. Ptytsi. Visnyk Sumskoho DAU. 5, 65-68 (in Ukrainian).

Melnyk, V.V. (2012). Morfometrychni parametry tymusa kachok. «Naukovi pratsi NUBiP Ukrainy «KATU», seriia «Veterynarni nauky». 148, 269-274 (in Ukrainian).

Melnyk, V.V. (2005). Do morfolohii selezinky kachok. Naukovyi visnyk NAU. 89, 107-109 (in Ukrainian).

Stehnei, Zh.H. (2013). Vikovi zminy morfometrychnykh pokaznykiv tymusa kacheniat Naukovyi visnyk NUBiP Ukrainy. 188(2), 166-169 (in Ukrainian).

Teltsov, L.P., Shashanov, Y.R. (1998). Krytycheskye fazy razvytyia zhyvotnukh y praktyka zhyvotnovodstva. Fundamentalnye y prykladnye problemy povyshenyia produktyvnosty selskokhoziaistvennykh zhyvotnykh. 52-53 (in Russian).

Teltsov, L.P., Ylyn, P.A., Stoliarov, V.A. (1993). Funktsyonalnaia morfolohyia $v$ embryoheneze: nauchnoe yzdanye. M.: Medytsyna (in Russian).

Topuryia L.Iu., Bokov, D.A. (2013). Strukturnofunktsyonalnaia kharakterystyka sumky Fabrytsyusa utok krossa Blahovarskyi $\mathrm{v}$ peryod nachala polovoho sozrevanyia pry prymenenyy Hermyvyta. Zh. Yzvestyia Orenburhskoho hosudarstvennoho ahrarnoho unyversyteta. 1(39), 74-76 (in Russian).

Yakymenko, L.L., Yakymenko, V.P. (2011). Sovremennue predstavlenyia o fabrytsyevoi burse ptyts. Uchenye zapysky UO «Vytebskaia ordena «Znak Pocheta» hosudarstvennaia akademyia veterynarnoi medytsyny». 47(1), 321-323 (in Russian).

Стаття надійшла до редакичї 5.09.2016 